\title{
PENGARUH PENAMBAHAN MINYAK KELAPA, MINYAK BIJI BUNGA MATAHARI, DAN MINYAK KELAPA SAWIT TERHADAP PENURUNAN PRODUKSI METAN DI DALAM RUMEN SECARA IN VITRO
}

\section{THE EFFECT OF ADDITION COCONUT OIL, SUNFLOWER SEED OIL, AND PALM OLEIN ON REDUCING RUMINAL METHANE PRODUCTION IN VITRO}

\author{
Puput Diah Sitoresmi*, Lies Mira Yusiati, dan Hari Hartadi \\ Fakultas Peternakan, Universitas Gadjah Mada, Jl. Fauna No.3, Bulaksumur, Yogyakarta, 55281
}

\section{INTISARI}

Penelitian ini bertujuan untuk mengetahui pengaruh penambahan minyak nabati, yang meliputi minyak kelapa, minyak biji bunga matahari, dan minyak kelapa sawit terhadap produksi metan, jumlah protozoa, kadar $\mathrm{NH}_{3}$, aktivitas carboximethyl cellulase (CMC-ase), dan kadar protein mikrobia pada fermentasi rumput raja dan bekatul oleh mikrobia rumen secara in vitro. Penelitian ini terdiri dari 2 macam perlakuan, yaitu melihat efek minyak kelapa, minyak biji bunga matahari, dan minyak kelapa sawit dan level penambahan minyak yaitu $0 \%, 2,5 \%, 5,0 \%$, dan 7,5\%. Setiap perlakuan terdiri dari 3 ulangan. Fermentasi dilakukan menggunakan Hohenheim gas test (HGT) pada suhu $39^{\circ} \mathrm{C}$ selama 72 jam. Pada akhir fermentasi dilakukan koleksi gas metan, pengamatan produksi gas, jumlah protozoa, kadar $\mathrm{NH}_{3}$, aktivitas carboximethyl cellulase (CMC-ase), kadar protein mikrobia, dan nilai $\mathrm{pH}$. Data yang diperoleh dianalisis variansi pola faktorial (3x4) dilanjutkan dengan uji Duncan's New Multiple Range Test (DMRT). Hasil penelitian menunjukkan bahwa rerata jumlah protozoa mengalami penurunan $(\mathrm{P}<0,05)$ sebesar 9,8\%, 20,85\%, dan 23,95\% dan diikuti dengan penurunan rerata produksi metan $(\mathrm{P}<0,01)$ sebesar $11,11 \%, 15,79 \%$, dan 18,51\% pada penambahan minyak sebanyak 2,5\%, 5,0\%, dan 7,5\% dibandingkan dengan kontrol, tetapi tidak berpengaruh terhadap kadar $\mathrm{NH}_{3}$, aktivitas carboximethyl cellulase (CMC-ase), dan kadar protein mikrobia. Dari hasil penelitian dapat diambil kesimpulan penambahan minyak kelapa paling besar pengaruhnya terhadap penurunan produksi metan melalui inhibisi protozoa dan penambahan minyak hingga level 5,0\% mampu menurunkan produksi metan sebesar 15,80\%.

(Kata kunci : Minyak kelapa, Minyak biji bunga matahari, Minyak kelapa sawit, Produksi metan, Jumlah protozoa, Fermentasi In Vitro)

\section{ABSTRACT}

This experiment was conducted to determine the effect of vegetable oil, such as coconut oil, sunflower seed oil, and palm olein on methane production, number of protozoa, microbial protein concentration, ammonia (NH $\left.\mathrm{N}_{3}\right)$ concentration and carboxymethyl cellulase (CMC-ase) activity in the vitro fermentation of king grass and rice bran by rumen microbial. The experiment consisted of two treatments (i.e.) the effect of coconut oil, sunflower seed oil, and palm olein and level of addition of vegetable oil i.e. $0 \%, 2.5 \%, 5.0 \%$, and $7.5 \%$. The fermentation was done using Hohenheim gas test (HGT) metode and incubated at $39^{\circ} \mathrm{C}$ for 72 hours with three replicates. At the end of the fermentation, methane concentration, number of protozoa, microbial protein concentration, $\mathrm{NH}_{3}$ concentration, $\mathrm{CMC}$ ase activity, and $\mathrm{pH}$ were observed. Data obtained were analyzed using analysis of variance and the design using factorial (3x4). The deferences of mean values were analyzed by Duncan's new multiple range test (DMRT). The result showed that the number of protozoa decreased $(P<0.05)$ as much as $9.8 \%, 20.85 \%$, and 23.95\%, followed by methane supression $(P<0.01)$ much as $11.11 \%, 15.79 \%$, and $18.51 \%$ with oil addition at level 2.5\%, 5.0\%, and 7.5\% compared to control, but no effect on microbial protein concentration, ammonia $\left(\mathrm{NH}_{3}\right)$ concentration and carboxymethyl cellulase (CMC-ase) activity. It can be concluded that coconut oil had the highest affect on methane production by inhibition of protozoa growth and addition oil up to $5.0 \%$ reduced methane production as much as $15.80 \%$.

(Key words : Coconut oil, Sunflower seed oil, Palm olein, Methane production, Protozoa count, In vitro fermentation)

\section{Pendahuluan}

Terjadinya kenaikan suhu bumi merupakan isu paling penting mengenai lingkungan hidup

\footnotetext{
* Korespondensi (corresponding author):

Telp. +6281328211608

E-mail: puputdsitoresmi@yahoo.com
}

(Jordan et al.,2006). Metan $\left(\mathrm{CH}_{4}\right)$ merupakan gas yang memiliki potensi 21 kali lebih besar membentuk gas rumah kaca dibanding karbon dioksida yang dapat menyebabkan terjadinya pemanasan global (Buddle et al., 2006). Terdapat berbagai macam sumber metan, salah satunya adalah metan yang dihasilkan oleh bakteri metanogen pada ternak 
ruminansia yang dilepaskan melalui proses eruktasi (Berra et al., 2005).

Lepasnya metan tidak hanya menyebabkan peningkatan konsentrasi $\mathrm{CH}_{4}$ di udara, namun juga menyebabkan hilangnya 6-13\% dari pakan (Miller et al., 2002). Kurang lebih $90 \%$ metan yang dihasilkan di dalam rumen, dirotasikan melalui pembuluh darah dan paru-paru dan berakhir pada pelepasan metan melalui mulut dan hidung, yang disebut dengan eruktasi, dan sebanyak 10\% metan dibuang melalui anus (Eckard et al., 2006).

Menurut Berg dan Kern (1999), $\mathrm{CH}_{4}$ diproduksi di dalam rumen utamanya dilakukan oleh bakteri dari grup archae yang disebut metanogen. Bakteri penghasil metan yang utama di dalam rumen adalah Methanobacterium ruminantium (Hungate, 1966), Methanobacterium mobilis $s p$. (Paynter dan Hungate, 1968), Methanobrevibacter sp. (Miller et al., 1986), Methanobacterium mobile, Methanosarcina, Methanobacterium formicicum, dan Methanobrevibacter smithii (Lovley et al., 1984). Metanogen mengkonversi $\mathrm{CO}_{2}$ dan $\mathrm{H}_{2}$ menjadi metan di dalam rumen (Eckard et al., 2006).

Mikroorganisme rumen utamanya bakteri, protozoa dan jamur berperan dalam hidrolisis pati yang terkandung di dalam pakan dan dinding sel polisakarida tanaman, sehingga menghasilkan glukosa, VFA, $\mathrm{CO}_{2}$ dan $\mathrm{H}_{2}$ (Miller, 1995). Ternak ruminansia memanfaatkan asetat, propionat, butirat, dan biomasa mikrobia sebagai prekursor proses biosintesis dan merupakan sumber energi dan sumber asam amino (Miller et al., 2002).

Aktivitas metabolisme protozoa sangat erat kaitannya dengan produksi metan di dalam rumen (Dohme et al., 1999). Metanogenesis yang terjadi di dalam rumen dipengaruhi oleh adanya mekanisme ecto- dan endosymbiosis antara ciliate protozoa dengan metanogen, yaitu melalui jalur spesifik dalam transfer $\mathrm{H}_{2}$ interspesies. Sebanyak 10-20\% dari total populasi metanogen dapat berikatan dengan ciliate protozoa. Simbiosis antara metanogen dengan ciliate protozoa berperan penting hingga $9-25 \%$ dalam proses metanogenesis di dalam rumen (Machmuller et al., 2003).

Minyak telah banyak digunakan untuk defaunasi dalam rumen (Dong et al., 1997). Pada kondisi penyelimutan protozoa oleh minyak, protozoa tidak memiliki aktivitas lipolitik sebaik bakteri, akibatnya aktivitas metabolik protozoa terganggu dan banyak protozoa yang mati pada kondisi lemak tinggi di dalam rumen (Tamminga dan Doreau, 1991). Minyak merupakan pakan alternatif yang bersifat alami yang dapat menghambat pelepasan metan (Moss et al., 2000). Asam laurat merupakan antiprotozoal paling kuat yang menghambat pertumbuhan dan aktivitas protozoa bersilia (utamanya Entodinium spp.), sedangkan jumlah protozoa semakin menurun seiring dengan semakin banyaknya ikatan rangkap yang terkandung di dalam asam lemak tidak jenuh berantai panjang (Hristov et al., 2004). Penurunan populasi ciliate protozoa akibat defaunasi menyebabkan penurunan simbiosis antara ciliate protozoa dengan metanogen, sehingga menurunkan ketersediaan hidrogen untuk pembentukan metan (Jordan et al., 2006).

Selanjutnya, penelitian berikut dilakukan untuk mengevaluasi pengaruh penambahan minyak kelapa, minyak kelapa sawit dan minyak biji bunga matahari terhadap produksi metan dalam rumen dengan menggunakan metode in vitro Hohenheim gas test (HGT).

\section{Materi dan Metode}

Dua ekor sapi Peranakan Ongole dewasa, yang diberi pakan hijauan berupa rumput raja dan konsentrat dengan komposisi hijauan konsentrat adalah 60:40 sebanyak 3\% berat badan (dalam bahan kering) secara ad libitum, digunakan sebagai donor cairan rumen untuk analisis in vitro produksi gas.

Bahan pakan berupa rumput raja dan bekatul sebanyak $250 \mathrm{mg}$ digunakan sebagai substrat. Pada kelompok perlakuan diberikan penambahan minyak kelapa, minyak kelapa sawit, dan minyak biji bunga matahari masing-masing sebanyak 2,5, 5,0; dan 7,5\% DM ke dalam pakan kontrol, yaitu rumput raja dan bekatul dengan komposisi 20:80.

Campuran cairan rumen dan buffer dimasukkan ke dalam syringe yang telah berisi bahan pakan yang akan dianalisis dengan menggunakan semi otomatis pipet sebanyak $30 \mathrm{ml}$, selanjutnya diinkubasi pada suhu $39^{\circ} \mathrm{C}$ selama satu malam. Gas $\mathrm{CO}_{2}$ dialirkan beberapa saat ( \pm 15 menit) sampai warna larutan dalam syringe berwarna kuning bening. Klip ditutup, kemudian tanda baca skala di baca sebagai Vo, dan kemudian syringe diinkubasikan pada suhu $39^{\circ} \mathrm{C}$. Kenaikan volume gas dicatat dengan interval waktu inkubasi:1, 2, 4, 6, 8, 12, 24, 36, 48, dan 72 jam (Menke et al., 1979), selanjutnya, dilakukan preparasi sampel untuk mengukur produksi metan, nilai $\mathrm{pH}$, jumlah protozoa, kadar VFA, kadar $\mathrm{NH}_{3}$, aktivitas CMC-ase, dan kadar protein mikrobia.

Setelah inkubasi selama 72 jam, diambil sampel gas hasil fermentasi sebanyak $10 \mathrm{ml}$ menggunakan spuit dan sampel gas disimpan di dalam vaccumtube untuk dianalisis kadar metan dengan menggunakan gas chromatography (GC). Produksi metan merupakan hasil kali volume produksi gas selama 72 jam dengan kadar metan. Setiap perlakuan dilakukan ulangan sebanyak tiga kali. 
Cairan hasil fermentasi kemudian disaring dengan menggunakan gochcrush yang diberi glass wool, sampai tidak ada sampel pakan yang tersisa di dalam syringe. Sampel filtrat diambil kemudian digunakan untuk mengukur derajat keasaman $(\mathrm{pH})$ dengan menggunakan $\mathrm{pH}$ meter merk Hanna yang telah dikalibrasi dengan buffer $\mathrm{pH} 7$, kemudian dilanjutkan dengan $\mathrm{pH}$ 4. Preparasi perhitungan protozoa dilakukan dengan menambahkan $0,8 \mathrm{ml}$ formaldehyed saline solution $(37 \% \quad(\mathrm{v} / \mathrm{v}))$ formaldehid $+0,9 \%(\mathrm{v} / \mathrm{v}) \mathrm{NaCl}$, dengan proporsi 1:9 pada $1 \mathrm{ml}$ sampel fitrat. Selanjutnya sampel dihitung dengan teknik mikroskopi dengan perhitungan langsung di bawah mikroskop menggunakan haemocytometer dengan perbesaran 40 kali (Diaz et al., 1993)

Sampel filtrat selanjutnya disentrifugasi 3000 g selama 15 menit, kemudian sebanyak $0,2 \mathrm{ml}$ supernatan ditambah dengan $1 \mathrm{ml}$ asam metafosforik, kemudian disentrifugasi $9000 \mathrm{~g}$ selama 10 menit, supernatan selanjutnya digunakan untuk pengukuran kadar volatile fatty acids (VFA) dengan menggunakan gas chromatography (GC) (Doreau et al., 1993). Sampel supernatan hasil sentrifugasi $3000 \mathrm{~g}$ diambil untuk dilakukan uji kadar $\mathrm{NH}_{3}$ dan digunakan untuk penentuan aktivitas CMC-ase menurut Halliwel et al., (1985). Endapan hasil sentrifugasi $13.000 \mathrm{~g}$ digunakan untuk mengukur kadar protein mikrobia dengan menggunakan metode Lowry menurut Plummer (1987).

Data yang diperoleh dari hasil penelitian dianalisis menggunakan analisis variansi, dengan rancangan acak lengkap pola faktorial $3 \times 4$ dan dilanjutkan dengan uji Duncan new Multiple Range Test (DMRT) untuk nilai rata-rata yang berbeda nyata (Astuti, 1981).

\section{Hasil dan Pembahasan}

\section{Pengaruh penambahan minyak nabati terhadap jumlah protozoa}

Pengaruh macam minyak nabati, berupa minyak kelapa, minyak biji bunga matahari, dan minyak kelapa sawit pada fermentasi substrat bekatul dan rumput raja dengan proporsi 80:20 terhadap rerata jumlah protozoa dapat dilihat pada Grafik 1. Hasil penelitian menunjukkan terdapat

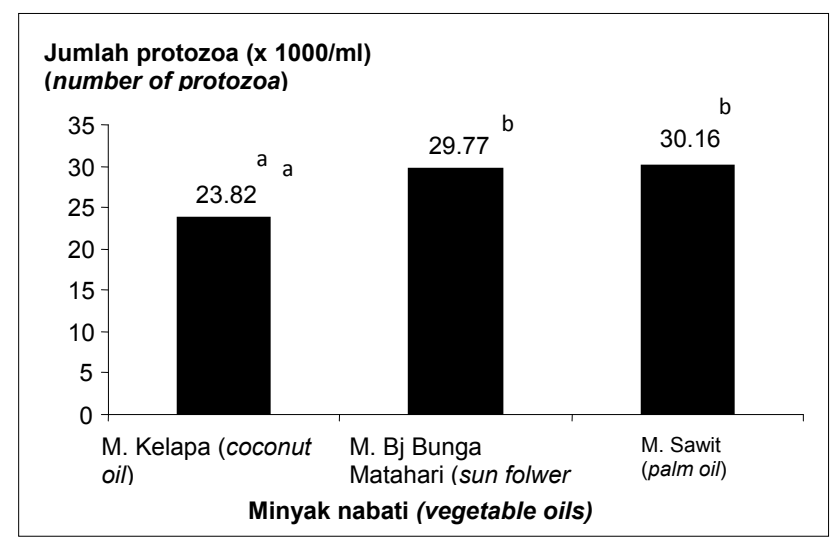

Grafik 1. Rerata jumlah protozoa pada fermentasi bekatul dan rumput raja dengan pemberian minyak nabati yang berbeda secara in vitro $\left(\mathrm{x}_{10} / \mathrm{ml}\right)$ (the average of protozoa count on in vitro fermentation of rice bran and king grass added with different vegetable oils $\left(\times 10^{3} / \mathrm{ml}\right)$ )

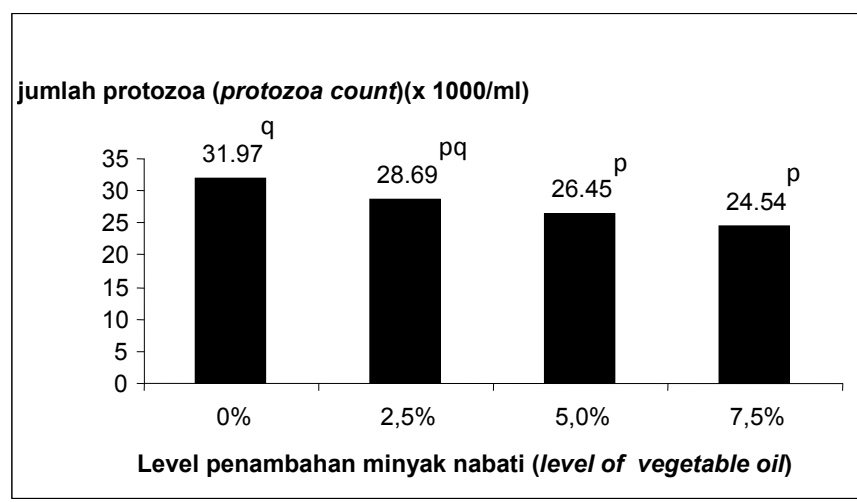

Grafik 2. Rerata jumlah protozoa pada fermentasi bekatul dan rumput raja dengan penambahanminyak pada level

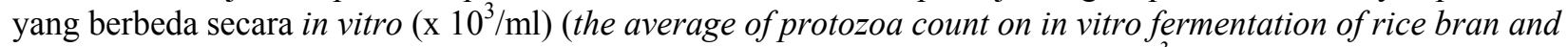
king grass added with different levels of vegetable oil $\left(x_{10^{3}} / \mathrm{ml}\right)$ ) 
pengaruh perbedaan macam minyak terhadap ratarata jumlah protozoa $(\mathrm{P}<0,05)$. Pemberian minyak kelapa (mengandung asam laurat 25,47\%, asam oleat $0,04 \%$, dan asam linoleat 2,36\%), memberikan efek yang paling besar terhadap rerata jumlah protozoa bila dibandingkan dengan pemberian minyak biji bunga matahari (asam asam laurat sebesar $0,08 \%$, asam oleat $67,12 \%$, dan asam linoleat $6,13 \%$ ), dan minyak kelapa sawit (asam laurat sebesar $0,06 \%$, asam oleat $46,14 \%$, dan asam linoleat $0,72 \%$ ). Namun demikian, rerata jumlah protozoa dengan pemberian minyak biji bunga matahari tidak berbeda nyata dengan rerata jumlah protozoa pada pemberian minyak kelapa sawit.

Penambahan Medium chain fatly acid (MCFA) berupa asam laurat murni sebanyak 5\% (wt/vol) pada substrat berupa biji barley $(90 \% \mathrm{DM})$ menyebabkan penurunan protozoa bersilia hingga mencapai $99,8 \%$, sedangkan penambahan MUFA (mono unsaturrated fatty acids) berupa asam oleat dan PUFA (polyunsaturrated fatty acids) berupa asam linoleat sebanyak $5 \%(\mathrm{w} / \mathrm{vol})$ pada substrat yang sama, berpengaruh secara nyata terhadap penurunan jumlah protozoa masing-masing sebesar 10,74\% dan 14,90\% (Hristov et al., 2004).

Penambahan minyak kelapa paling besar pengaruhnya terhadap defaunasi, hal ini disebabkan karena MCFA yang terkandung di dalam minyak kelapa yaitu asam laurat dapat meningkatkan sensitivitas mikrobia pada struktur dinding sel, sehingga dapat menghambat ciliate protozoa dan gram positif archaea (Machmuller, 2006).

Pengaruh penambahan minyak nabati dengan level penambahan yang berbeda pada fermentasi substrat bekatul dan rumput raja dengan proporsi 80:20 terhadap rerata jumlah protozoa dapat dilihat pada Grafik 2.

Penambahan minyak sebanyak $2,5 \%, 5,0 \%$, dan $7,5 \%$ secara signifikan menyebabkan penurunan rata-rata jumlah protozoa $(\mathrm{P}<0,05)$, masing-masing sebesar $9,8 \%, 20,85 \%$, dan $23,95 \%$.
Namun demikian, penambahan minyak hingga level $5,0 \%$ baru dapat menyebabkan penurunan secara nyata, sedangkan penambahan minyak hingga level $7,5 \%$ tidak berbeda secara nyata dengan penambahan minyak pada level 5,0\%.

Menurut Cieślak et al. (2006), jumlah protozoa pada fermentasi rumen yang mengandung substrat tepung gandum dan hay dengan imbangan 60:40 secara in vitro adalah sebesar 33,4 (x 103/ $\mathrm{ml})$. Penambahan minyak kelapa sebesar 1,0\% DMI dalam ransum pakan menyebabkan efek defaunasi protozoa di dalam rumen sapi sebesar 62,5\% (Jordan et al., 2006). Penambahan minyak rapeseed dan minyak linseed masing-masing sebanyak 7,0\% DMI pada ransum menyebabkan penurunan jumlah protozoa berturut-turut sebesar $30,77 \%$ dan $36,15 \%$ (Cieślak et al., 2006).

Efek negatif penambahan minyak terhadap mikrobia rumen adalah kemampuan sisi aktif dari asam-asam lemak membungkus dinding sel pakan dan menghambat transfer nutrien yang essensial (Dohme et al., 1999). Pada kondisi penyelimutan protozoa oleh minyak, protozoa tidak memiliki aktivitas lipolitik sebaik bakteri, akibatnya aktivitas metabolik protozoa menjadi terganggu dan banyak protozoa yang mati pada kondisi lemak tinggi di rumen (Tamminga dan Doreau, 1991).

\section{Pengaruh penambahan minyak nabati terhadap produksi metan}

Pengaruh macam minyak nabati, berupa minyak kelapa, minyak biji bunga matahari, dan minyak kelapa sawit pada fermentasi substrat bekatul dan rumput raja dengan proporsi 80:20 terhadap rerata produksi gas metan $(\mathrm{ml})$ dapat dilihat pada Grafik 3.

Hasil penelitian menunjukkan terdapat pengaruh perbedaan macam minyak terhadap ratarata produksi metan $(\mathrm{P}<0,01)$. Pemberian minyak kelapa memberikan pengaruh yang paling besar terhadap rata-rata produksi gas metan, yaitu

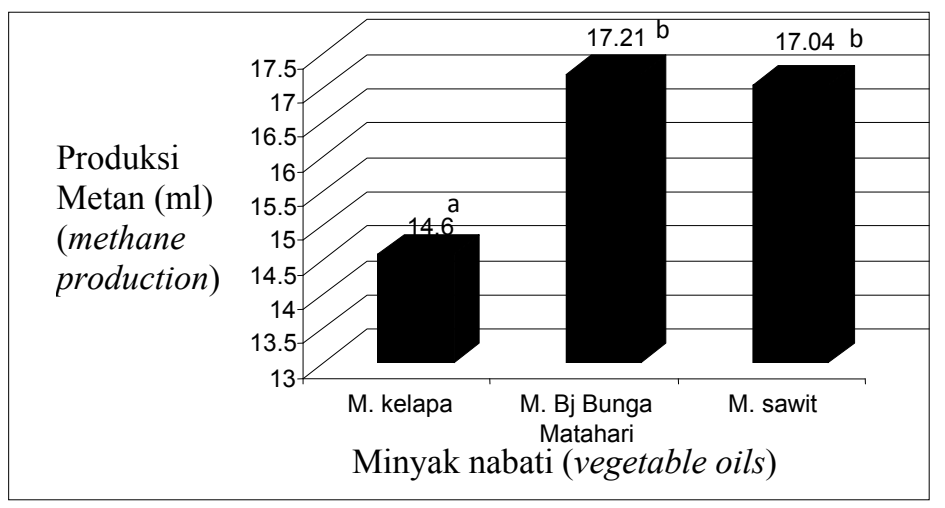

Grafik 3. Rerata produksi gas metan pada fermentasi bekatul dan rumput raja dengan pemberian minyak nabati yang berbeda secara in vitro $\left(\mathrm{x} 10^{3} / \mathrm{ml}\right)$ (the average of methane production on in vitro fermentation of rice bran and king grass added with different vegetable oils $\left.\left(x 10^{3} / \mathrm{ml}\right)\right)$ 


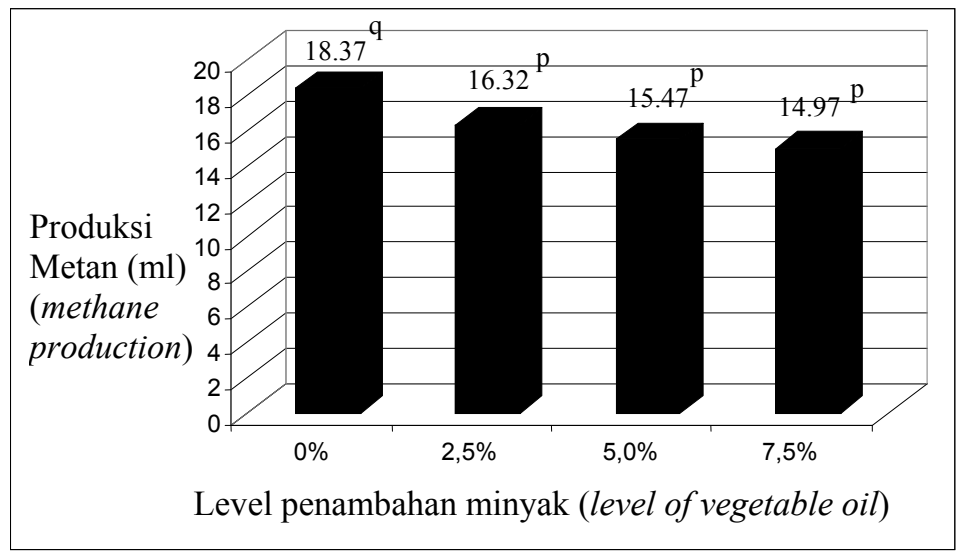

Grafik 4. Rerata produksi gas metan pada fermentasi bekatul dan rumput raja dengan penambahan minyak pada level yang berbeda secara in vitro $(\mathrm{ml})$ (the average of methane production on in vitro fermentation of rice bran and king grass added with different level of vegetable oil $(\mathrm{ml})$ )

menghasilkan produksi gas metan yang paling kecil bila dibandingkan dengan produksi gas metan yang dihasilkan pada pemberian minyak biji bunga matahari, dan minyak kelapa sawit, namun demikian pengaruh pemberian minyak biji bunga matahari terhadap rata-rata produksi gas metan tidak berbeda dengan pemberian minyak kelapa sawit.

Menurut Soliva et al., (2003), penambahan asam laurat $(\mathrm{C}: 12)$ dan asam miristat $(\mathrm{C}: 14)$ yang tidak teresterifikasi dengan jumlah pemberian $\mathrm{C}: 12$ dan C:14 yang berbeda, yaitu $10 \mathrm{mg} \mathrm{C:12}$ dan 20 mg C:14; 15 mg C:12 dan 15 mg C:14; 20 mg C:12 dan $10 \mathrm{mg}$ C:14 ke dalam fermentasi substrat berupa hay dan konsentrat secara in vitro dengan masa inkubasi selama 24 jam, dengan proporsi 60:40, berpengaruh secara nyata terhadap penurunan produksi metan masing-masing sebesar $50 \%, 87 \%$, dan $96 \%$.

Hasil penelitian menunjukkan pemberian minyak kelapa yang memiliki efek paling besar terhadap defaunasi, diikuti dengan rendahnya ratarata produksi metan yang dihasilkan. Hal ini disebabkan karena minyak kelapa mengandung asam laurat (MCFA) yang bersifat paling toksik terhadap protozoa (Hristov et al., 2004). Defaunasi menyebabkan turunnya mekanisme simbiosis antara metanogen dengan ciliate protozoa, sehingga hanya sedikit hidrogen yang dapat dikonversikan menjadi metan (Jordan et al., 2006).

Pengaruh penambahan minyak nabati dengan level penambahan yang berbeda pada fermentasi substrat bekatul dan rumput raja dengan proporsi 80:20 terhadap rerata produksi gas metan $(\mathrm{ml})$ dapat dilihat pada Grafik 4.

Penambahan minyak sebanyak $2,5 \%, 5,0 \%$, dan $7,5 \%$ menyebabkan penurunan rata-rata produksi metan, yaitu masing-masing sebesar $11,11 \%, \quad 15,79 \%$, dan $18,51 \%$. Hasil analisis statistik menunjukkan rata-rata produksi metan pada penambahan minyak hingga level 7,5\% tidak berbeda dengan penambahan minyak sebanyak $2,5 \%$ dan $5,0 \%$, namun berbeda nyata $(\mathrm{P}<0,01)$ dengan perlakuan tanpa penambahan minyak.

Penambahan minyak rapeseed dengan level sebanyak $7 \%$ dapat menurunkan produksi metan, yaitu sebesar $8,76 \%$, sedangkan penurunan produksi metan lebih besar terjadi pada penambahan minyak kedelai sebanyak $6 \%$ dan penambahan asam laurat dan asam miristat yang tidak teresterifikasi dengan perbandingan 2:1 (seperti yang terkandung dalam minyak kelapa), yakni menyebabkan penurunan produksi metan masing-masing sebesar $37,43 \%$ dan $96 \%$. Penambahan minyak ikan lemuru (sardine oil) pada substrat rumput raja secara in vitro hingga level 5,0\% mampu menurunkan produksi metan hingga 74,49\% (Yusiati et al., 2008).

Perbedaan nilai penurunan produksi metan tersebut, dapat disebabkan karena penggunaan substrat dan proporsi pemberian yang berbeda, jumlah asam lemak yang terkandung di dalam minyak, serta bentuk asam lemak yang teresterifikasi maupun asam lemak yang tidak teresterifikasi yang ditambahkan ke dalam ransum. Semakin besar level penambahan minyak cenderung menyebabkan semakin rendahnya produksi gas metan yang dihasilkan dalam fermentasi substrat bekatul dan rumput raja.

\section{Pengaruh penambahan minyak nabati terhadap kadar amonia/ $\mathbf{N H}_{3}$}

Hasil pengukuran kadar amonia pada fermentasi substrat bekatul dan rumput raja dengan pemberian minyak kelapa, minyak biji bunga matahari, dan minyak kelapa sawit, dapat dilihat pada Tabel 1.

Hasil penelitian menunjukkan tidak terdapat pengaruh macam minyak, yaitu berupa minyak kelapa, minyak biji bunga matahari, dan minyak 
Tabel 1. Kadar amonia pada fermentasi bekatul dan rumput raja dengan pemberian minyak yang berbeda secara in vitro $(\mathrm{mg} / 100 \mathrm{ml})$ (amonia concetration on in vitro fermentation of rice bran and king grass added with different levels vegetable oil $(\mathrm{mg} / 100 \mathrm{ml})$ )

\begin{tabular}{ccccc}
\hline \hline \multirow{2}{*}{$\begin{array}{c}\text { Level minyak (\%) } \\
\text { (oil level (\%) })\end{array}$} & $\begin{array}{c}\text { Minyak kelapa } \\
\text { (coconut oil) }\end{array}$ & $\begin{array}{c}\text { Minyak biji bunga matahari } \\
\text { (sun flower seed oil) }\end{array}$ & $\begin{array}{c}\text { Minyak kelapa sawit } \\
\text { (palm oil) }\end{array}$ & $\begin{array}{c}\text { Rerata } \\
\text { (average) }^{\mathrm{ns}}\end{array}$ \\
\hline 0,0 & 33,64 & 33,72 & 34,64 & 34,00 \\
2,5 & 33,55 & 32,90 & 33,28 & 33,24 \\
5,0 & 34,25 & 34,00 & 35,37 & 34,53 \\
7,5 & 33,91 & 33,69 & 35,20 & 34,27 \\
\hline Rerata (average) $^{\mathrm{ns}}$ & 33,84 & 33,57 & 34,62 & \\
\hline
\end{tabular}

${ }^{\mathrm{ns}}$ tidak berbeda nyata (non significant difference).

Tabel 2. Aktivitas CMC-ase pada fermentasi bekatul dan rumput raja dengan pemberian minyak yang berbeda secara in vitro (U/g) (CMC-ase activity on in vitro fermentation of rice bran and king grass added with different levels of vegetable oil (U/g))

\begin{tabular}{ccccc}
\hline \hline $\begin{array}{c}\text { Level minyak (\%) } \\
\text { (oil level (\%) }\end{array}$ & $\begin{array}{c}\text { Minyak kelapa } \\
(\text { coconut oil) }\end{array}$ & $\begin{array}{c}\text { Minyak biji bunga matahari } \\
(\text { sun flower seed oil) }\end{array}$ & $\begin{array}{c}\text { Minyak kelapa sawit } \\
\text { (palm oil) }\end{array}$ & $\begin{array}{c}\text { Rerata } \\
(\text { average })^{\text {ns }}\end{array}$ \\
\hline 0,0 & 6,84 & 6,19 & 6,42 & 6,48 \\
2,5 & 5,11 & 4,68 & 5,72 & 5,17 \\
5,0 & 4,90 & 5,15 & 4,85 & 4,97 \\
7,5 & 4,43 & 5,87 & 4,32 & 4,87 \\
\hline Rerata (average) & 5,32 & 5,47 & 5,33 & \\
\hline
\end{tabular}

${ }^{\mathrm{ns}}$ tidak berbeda nyata (non significant difference).

kelapa sawit terhadap rata-rata kadar amonia, sedangkan rata-rata kadar amonia pada penambahan minyak hingga level 7,5\% juga tidak berbeda secara nyata dengan perlakuan tanpa penambahan minyak.

Rata-rata kadar amonia pada penambahan minyak nabati hingga level 7,5\% berkisar antara 33,24-34,53 mg/100ml, lebih besar dari kadar amonia pada penambahan minyak ikan lemuru sebanyak 2,5\%, yaitu 6,86 mg/100ml (Yusiati et al., 2008), namun tidak jauh berbeda dengan kadar amonia pada penambahan MCFA, MUFA, dan PUFA sebanyak 0,25\% (wt/vol), yaitu 29,63 $\mathrm{mg} / 100 \mathrm{ml}$ (Hristov et al., 2004). Namun demikian, kadar amonia yang dihasilkan dari penambahan berbagai macam minyak dan asam lemak masih dalam kisaran yang normal untuk sintesis dan pertumbuhan protein mikrobia. McDonald et al. (2002) melaporkan bahwa, konsentrasi $\mathrm{NH}_{3}$ dalam rumen sapi berkisar 85-300 mg/l, sedangkan kadar amonia sampai dengan $80 \mathrm{mg} / 100 \mathrm{ml}$ dilaporkan tidak mengganggu pertumbuhan mikrobia rumen (Satter dan Slyter, 1972). Hasil penelitian menunjukkan penambahan minyak nabati hingga level 7,5\% tidak berefek negatif terhadap kadar amonia yang menjadi sumber nitrogen utama untuk sintesis asam amino bagi mikrobia rumen.

\section{Pengaruh penambahan minyak nabati terhadap aktivitas CMC-ase}

Pengaruh macam minyak yang berbeda, yaitu berupa minyak kelapa, minyak biji bunga matahari, dan minyak kelapa sawit dengan level yang berbeda pada fermentasi substrat bekatul dan rumput raja terhadap kadar protein mikrobia dapat dilihat pada Tabel 2.

Hasil penelitian menunjukkan tidak terdapat pengaruh macam minyak, yaitu berupa minyak kelapa, minyak biji bunga matahari, dan minyak kelapa sawit terhadap rata-rata aktivitas CMC-ase, sedangkan rata-rata aktivitas CMC-ase pada penambahan minyak hingga level 7,5\% juga tidak berbeda secara nyata dengan perlakuan tanpa minyak.

Penambahan 10 macam asam-asam lemak yang merupakan medium chain fatty acids (MCFA) dan polyunsaturrated fatty acids (PUFA) ke dalam pakan basal berupa biji barley dengan level 0,25, 0,50, dan 1,0\% (wt/vol), tidak mempengaruhi aktivitas enzim pendegradasi polisakarida (CMCase, xilanase, dan amilase) (Hristov et al., 2004). Penambahan minyak ikan lemuru (sardine oil) pada substrat rumput raja secara in vitro hingga level 7,5\% tidak berpengaruh terhadap aktivitas CMC-ase dan memiliki kisaran aktivitas CMC-ase sebesar 
0,93-1,09 U/g protein (Yusiati et al., 2008). Penambahan crude palm oil (CPO) hingga 7,5\% pada fermentasi rumput raja secara in vitro memiliki kisaran aktivitas CMC-ase sebesar 1,09-2,59 U/g (Setyawati, 2008).

Penambahan minyak nabati tidak berpengaruh secara nyata terhadap kadar amonia, dimana bakteri selulolitik mempunyai kebutuhan spesifik akan amonia untuk mensintesis protein tubuhnya, hal ini berakibat pada tidak terjadinya kenaikan konsentrasi protein mikrobia, sehingga diperkirakan tidak berpengaruh juga terhadap aktivitas bakteri selulolitik untuk mensekresikan enzim CMC-ase yang berperan untuk mendegradasi selulosa yang merupakan polisakarida yang terkandung di dalam pakan.

\section{Pengaruh penambahan minyak nabati terhadap kadar volatile fatty acid (VFA)}

Hasil pengukuran kadar VFA pada fermentasi substrat bekatul dan rumput raja dengan pemberian macam minyak yang berbeda, yaitu minyak kelapa, minyak biji bunga matahari, dan minyak kelapa sawit, dapat dilihat pada Grafik 5.

Hasil penelitian menunjukkan bahwa tidak terdapat pengaruh perbedaan macam minyak terhadap rata-rata kadar asam asetat, namun secara nyata $(\mathrm{P}<0,01)$ berpengaruh terhadap rata-rata kadar asam propionat dan asam butirat. Penambahan minyak hingga level 7,5\% tidak berpengaruh secara nyata terhadap rerata kadar asam asetat, asam propionat, dan asam butirat.

Menurut Wei-lian et al. (2005), total konsentrasi volatile fatty acids (VFA) menurun akibat defaunasi, namun terjadi peningkatan molar propionat. Hasil penelitian menunjukkan rata-rata kadar asam propionat pada pemberian minyak kelapa lebih tinggi bila dibandingkan dengan pemberian minyak biji bunga matahari dan minyak kelapa sawit, masing-masing memiliki kadar asam propionat (mMol) sebesar 5,16 vs. 3,90 vs. 3,70.

Kadar asam asetat, asam propionat, dan asam butirat pada penambahan minyak rapeseed dan minyak linseed dengan level $9,0 \%$ pada pakan berupa konsentrat dengan proporsi $60 \%$ masingmasing adalah 53,1, 23,4, dan 16,8 (mol \%), sedangkan dengan penambahan minyak linseed, kadar asam asetat, asam propionat dan asam butirat masing-masing adalah 53,7, 24,9, dan 14,5 (Machmüller et al., 1998). Penambahan minyak ikan lemuru hingga level 7,5\% DM memiliki kisaran kadar asam asetat sebesar 37,12-41,99 $(\mu \mathrm{mol})$, kadar asam propionat 12,37-13,75 ( $\mu \mathrm{mol})$, kadar asam butirat 4,15-4,66 ( $\mu \mathrm{mol})$, serta imbangan $\mathrm{C}_{2}: \mathrm{C}_{3}$ sebesar 2,91-3,05 (Yusiati et al., 2008).

Hasil penelitian menunjukkan imbangan C2:C3 berkisar antara 2,398-3,283, lebih tinggi bila dibandingkan dengan imbangan $\mathrm{C} 2: \mathrm{C} 3$ pada penambahan $\mathrm{C} 12: 0, \mathrm{C} 18: 1$, dan $\mathrm{C} 18: 2$ sebanyak 1,0\% (wt/vol) (Hristov et al., 2004), tetapi tidak berbeda dengan kisaran imbangan $\mathrm{C}_{2}: \mathrm{C}_{3}$ pada penambahan minyak ikan lemuru menurut Yusiati et al. (2008), hal ini dapat disebabkan karena perbedaan pemberian macam dan proporsi substrat serta perbedaan penambahan macam dan bentuk asam lemak. Namun demikian, imbangan $\mathrm{C}_{2}: \mathrm{C}_{3}$ hasil penelitian tersebut masih dalam kisaran normal. Menurut Hungate et al. (1961) pada kondisi normal, rasio molar asetat dan propionat adalah 3,125 . Pada ruminansia yang diberi ransum berupa biji-bijian, imbangan $\mathrm{C}_{2}: \mathrm{C}_{3}$ berkisar antara $0,93-$ 1,68 , namun dalam kondisi normal memiliki imbangan asetat : propionat berkisar antara 2,373,66 (Davis, 1967).

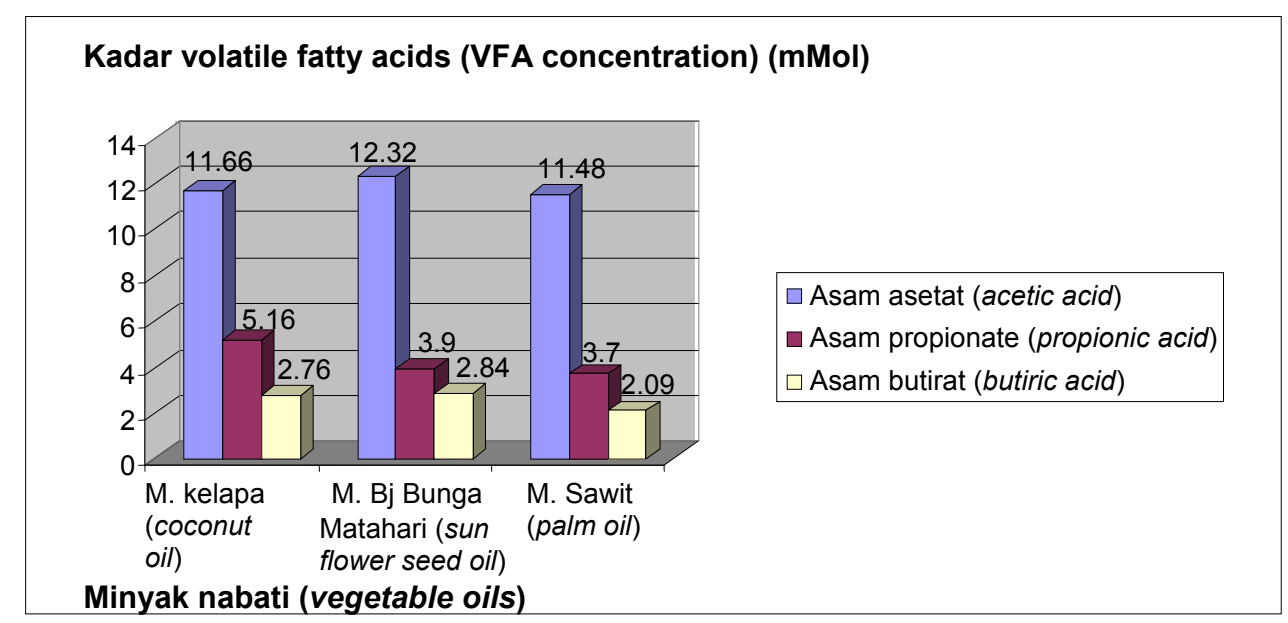

Grafik 5. Rerata kadar VFA pada fermentasi bekatul dan rumput raja dengan pemberian minyak nabati yang berbeda secara in vitro ( $\mathrm{mMol}$ ) (the average of VFA concentration in vitro fermentation of rice bran and king grass added with different levels of vegetable oil ( $\mathrm{mMol})$ ) 
Tabel 3. Kadar protein mikrobia pada fermentasi bekatul dan rumput raja dengan penambahan minyak kelapa, minyak biji bunga matahari, dan minyak kelapa sawit secara in vitro $(\mathrm{mg} / \mathrm{ml})$ (microbial protein concetration on in vitro fermantation of rice bran and king grass added with coconut oil, sun flower seed oil and palm oil)

\begin{tabular}{|c|c|c|c|c|}
\hline \multirow[b]{2}{*}{$\begin{array}{l}\text { Level minyak (\%) } \\
\text { (oil level }(\%))\end{array}$} & \multicolumn{3}{|c|}{ Tipe minyak (oil type) } & \multirow[b]{2}{*}{$\begin{array}{c}\text { Rerata } \\
(\text { average })^{\mathrm{ns}}\end{array}$} \\
\hline & $\begin{array}{l}\text { Minyak kelapa } \\
\text { (oil coconut) }\end{array}$ & $\begin{array}{l}\text { Minyak biji bunga matahari } \\
\text { (sun flower seed oil) }\end{array}$ & $\begin{array}{l}\text { Minyak kelapa sawit } \\
\text { (palm oil) }\end{array}$ & \\
\hline 0,0 & 0,41 & 0,41 & 0,41 & 0,41 \\
\hline 2,5 & 0,38 & 0,39 & 0,40 & 0,39 \\
\hline 5,0 & 0,38 & 0,40 & 0,40 & 0,39 \\
\hline 7,5 & 0,39 & 0,40 & 0,38 & 0,39 \\
\hline Rerata (average) n $^{\mathrm{ns}}$ & 0,39 & 0,40 & 0,40 & \\
\hline
\end{tabular}

${ }^{n}$ tidak berbeda nyata (non significant difference).

\section{Pengaruh penambahan minyak nabati terhadap protein mikrobia}

Pengaruh pemberian macam minyak yang berbeda, yaitu minyak kelapa, minyak biji bunga matahari, dan minyak kelapa sawit dengan level yang berbeda pada fermentasi substrat bekatul dan rumput raja terhadap kadar protein mikrobia dapat dilihat pada Tabel 3 .

Hasil penelitian menunjukkan tidak terdapat pengaruh macam minyak, yaitu berupa minyak kelapa, minyak biji bunga matahari, dan minyak kelapa sawit terhadap rata-rata kadar protein mikrobia, sedangkan rata-rata kadar protein mikrobia pada penambahan minyak hingga level $7,5 \%$ juga tidak berbeda secara nyata $(\mathrm{P}>0,05)$ dengan perlakuan tanpa penambahan minyak.

Rata-rata kadar protein mikrobia pada pemberian minyak hingga level $7,5 \%$, berkisar 0,39-0,41 $\mathrm{mg} / \mathrm{ml}$, tidak berbeda jauh dengan kisaran kadar protein mikrobia pada penambahan minyak ikan lemuru sebanyak 2,5\% DM, yaitu 0,41-0,51 $\mathrm{mg} / \mathrm{ml}$ menurut Yusiati et al. (2008) dan kisaran kadar protein mikrobia pada penambahan crude palm oil (CPO) hingga 7,5\%, yaitu 0,33-0,51 mg/ml (Setyawati, 2008). Hal ini menunjukkan bahwa penambahan minyak kelapa, minyak biji bunga matahari, dan minyak kelapa sawit hingga level 7,5\% tidak berefek negatif terhadap kadar protein mikrobia dan masih berada dalam kisaran normal.

Ørskov (1992) menyatakan bahwa, prekursor untuk sintesis protein mikrobia, yaitu tersedianya kerangka karbon yang cukup, $\mathrm{NH}_{3}$, dan energi. Hasil penelitian menunjukkan penambahan minyak nabati hingga level 7,5\% tidak berpengaruh secara nyata terhadap kadar $\mathrm{NH}_{3}$ (sebagai sumber $\mathrm{N}$ ) dan total volatile fatty acid (sebagai sumber energi dan kerangka karbon), sehingga keduanya tidak cukup mendukung untuk terjadinya peningkatan sintesis protein mikrobia.

\section{Kesimpulan}

Pemberian minyak kelapa paling besar pengaruhnya terhadap penurunan jumlah protozoa dan produksi metan, serta kadar asam propionat dibandingkan dengan pemberian minyak biji bunga matahari dan minyak kelapa sawit. Penambahan minyak hingga level 5,0\% mampu menurunkan produksi metan hingga $15,80 \%$ tanpa berefek negatif terhadap kadar $\mathrm{NH}_{3}$, kadar VFA, aktivitas CMC-ase, dan kadar protein mikrobia.

\section{Saran}

Perlu dilakukan penelitian lanjutan tentang manfaat suplementasi minyak nabati sebagai sumber energi dan nasib asam-asam lemak tidak jenuh di dalam rumen sebagai asam lemak essensial yang diperlukan oleh inang.

\section{Daftar Pustaka}

Astuti, M. 1981. Rancangan Percobaan dan Analisis Statistik. Bagian II. Fakultas Peternakan Universitas Gadjah Mada. Yogyakarta.

Berg, W., and J.Kern. 1999. Influence of milk production level on methane emission from dairy cattle. Leibniz-Institute for Agricultural Engineering Postdam_Bornim (ATB), D14469 Postdam, Germany.

Berra, G., S.E. Valtorta, L. Finster, E.Mangano, F.Barrera, L.Fraigi. 2005. A simple technique for measuring enteric methane emission in cows. Instituto de Patobiologia, Centro de Investigaciones Veterinarist y Agronomicas, Inta Castelar, Buenos Aires, Argentina.

Buddle, B.M., D.N. Wedlock, G. Pederson, and M. Denis. 2006. Towards a vaccine against methanogens. AgResearch, Hopkirk Research Institute, Palmerston, North, New Zealand. 
Ciéslak, A., R. Miltko, G.Belźecki, M.SzumacherStrabel, A.Potkański, E.Kwiatkowska, and T.Michalowski. 2006. Effect of vegetable oils on the methane concentration and population density of the rumen ciliate, Eremoplastron dilobum, grown in vitro. Journal of Animal and Feed Sciences 15 (1): 15-18.

Ciéslak, A., M.Szumacher-Strabel, E.Szymankiewics, M. Piękniewski, P.Oleszak, L.Siwiński, and A.Potkański. 2006. Coconut oil reduces protozoa count and methane release during fermentation in a Rusitec system. Journal of Animal and Feed Sciences 15 (1): 19-22.

Davis, C.L. 1967. Acetate Production in the Rumen of Cows Feed Either Control or Low-Fiber, High-Grain Diets. Department of Dairy Science, University of Illinois, Urbana. J.dairy Science Vol.50 No. 10: 1621-1625.

Diaz, A., Avendro M. and Escobar A. 1993. Evaluation of sapindus saponaria as a defaunating agent and its effects on different ruminal digestion parameters. Livestock research for Rural Development, Vol. 5, Number 2.

Dohme, F., A. Machmüller, B.L. Esterman, P.Pfister, A. Wasserfallen, and M. Kreuzer. 1999. The role of the rumen protozoa for methane suppression caused by coconut oil. Letters in Applied Microbiology 29: 187-192.

Dong, Y., H.D. Bae, T.A. McAllister, G.W. Mathison, and K.J. Cheng. 1997. Lipidinduced depression of methane production and digestibility in the artificial rumen system (RUSITEC). Can. J.Anim Sci. 77: 269-278.

Doreau, M.B. Salem and R.R. Krezminski. 1993. Effect of rapeseed oil supply on in vitro ruminal digestion in cows: comparison of hay and maize silage diets. J.Anim.Feed Sci. and Technol. 44: 181-189.

Eckard, R., D. Dalley, and M. Crawford. 2006. Dairy production system in Australia in Grazing system-pasture and rangelands. Paper and presentation. Section three. pp: 57-88.

Halliwel, G., N.N.B.A. Wahab, and A.H. Patle. 1985. Chemical composition of endo 1,4- $\beta$ glucanase to cellulolitic in trichoderma koningii. J.App.Biochemistry. 7: 43-45.

Hristov, A.N., M. Ivan, and T.A. McAllister. 2004. In vitro effects on individual fatty acids on protozoal numbers and on fermentation products in ruminal fluid from cattle fed a high concentrate, barley-based diet. J. Anim. Sci. 82: 2693-2704.
Hungate, R.E., Robert A. Mah, and Mogen Simesen. 1961. Rates of Production of Individual Volatile Fatty Acids in the Rumen of Lactating Cows. Departments of Bacteriology and Animal Husbandry. University of California. J.Anim.Sci. 9:554-561.

Hungate, R.E. 1966. The Rumen and Its Microbe. Academic Press. pp. 78-79.

Jordan, E., D. Kenny, M. Hawkins, R. Malone, D. K. Lovett, and F. P. O'Mara. 2006. Effect oy refined soy oil or whole soybeans on intake, methane output, and performance of young bulls. J.Anim.Sci. 84: 2418-2425.

Jordan, E., D.K. Lovett, F.J. Monahan, J. Callan, B. Flynn, and F.P. O'Mara. 2006. Effect of refined coconut oil or copra meal on methane ouput and on intake and performance of beef heifers. J.Anim.Sci. 84: 162-170.

Lovley, D.R., R.C. Greening, J.G. Ferry. 1984. Rapidly Growing Rumen Methanogenic Organism that Synthesize Coenzym M and Has a High Affinty for Formate. Applied and Environmental Microbiology. American Sociey for Microbiology. 48: 81-87.

Machmüller, A., D.A. Ossowski, M. Wanner, and M. Kreuzer. 1998. Potential of various fatty feeds to reduce methane release from rumen fermentation in vitro (Rusitec). Animal Feed Science Tech. 71: 117-130.

Machmüller, A. 2006. Medium-chain fatty acids and their potential to reduce methanogenesis in domestic ruminants. Agriculture, Ecosystems and Environment. 112: 107-114.

Machmüller, A., C.R. Soliva, and M. Kreuzer. 2003. Effect of coconut oil and defaunation treatment on methanogenesis in sheep. Reprod.Nutr.Dev. 43: 41-55.

Mc.Donald, P., R. A. Edwards, J. F. D. Greenhalgh, and C. A. Morgan. 2002. Animal Nutrition. $6^{\text {th }}$ ed. Ashford Colour Press Ltd, Gosport. pp. 515-535.

Menke, K.H., Raab, L., Salewski, A, Steingasaa, H., Fritz,D., and Schneider, W. 1979. The estimation of the digestibility and metabolizable energy content of ruminant feeding stuff from the gas production when they are incubated with rumen liquor in vitro. Journal of Agriculture Sci. 93: 217-222.

Miller, T.L, M.J. Wolin, Z. Hongxue, M.P. Bryant. 1986. Characteristics of Methanogens Isolated from Bovine Rumen. Applied and Environmental Microbiology. American Sociey for Microbiology. 51: 201-202.

Miller, D. 1995. Environmental considerations of livestock producers. J.Anim.Sci. 73: 27332740. 
Miller, T.L, M.J. Wolin, Z. Hongxue, M.P. Bryant. 2002. Characteristics of Methanogens Isolated from Bovine Rumen. Applied and Environmental Microbiology. American Sociey for Microbiology. 51: 201-202.

Moss, A.R., Jouany, J.P., Newbold, J. 2000. Methane production by ruminants: its contribution to global warming. Ann. Zootech. 49: 231-253.

Orskov, E. R. 1992. Protein Nutrition In Ruminant. $2^{\text {nd }}$ Ed. Published by Academic Press Limited, London.

Paynter, M.J.B. and R.E. Hungate. 1968. Characterization of Methanobacterium mobilis, sp.n., Isolated from the Bovine Rumen. J. of Bacteriology. 95:1943-1951.

Plummer, D.T. 1987. An Introduction to Practical Biochemistry. Mc. Graw Hill Ltd. Bombay. New Delhi.

Satter,L.D. and L.L. Slyter. 1972. Effect of ammonia concentration on ruminal microbes in vitro. J.Anim.Sci. 35: 237-280.

Setyawati, R. 2008. Pengaruh Proteksi minyak Kelapa Sawit Menggunakan Formaldehid terhadap Jumlah Protozoa dan Produk Fermentasi Mikrobia Rumen secara In Vitro. Skripsi. Fakultas Peternakan UGM.

Soliva, C.R., I.K. Hindrichsen, L.Meile, M. Kreuzer, and A. Machmüller. 2003. Effects of mixture of lauric and myristic acid on rumen methanogens and methanogenesis in vitro. Letters in Applied Microbiology. 37: 35-39.
Tamminga, S., and M. Doreau. 1991. Lipids and rumen digestion. In: J.P. Jouany (Ed.) rumen Microbial Metabolism and Ruminal Digestion. p 151. INRA. Paris. France.

Wei-lian, HU, WU Yue-ming, LIU Jian-xin, GUO Yan-qiu, and YE Jun-an. 2005. Tea saponins affect in vitro fermentation and methanogenesis in faunated and defaunated rumen fluid. Journal of Zhejiang University Science. 6B(8): 787-792. ISSN 1009-3095.

Yusiati, L.M., Z. Bachruddin, C. Hanim, E. Lestari. 2008. The effect of sardine (sardinelle longiceps) oil as a source of methanogenesis inhibitor agent on the rumen fermentation product of the diet containing different level of forages. In: Management Strategy of Animal Health and Production Control on Anticipation Global Warming for Achievment of Millenium Development Goals. Faculty of Veterinary Medicine Airlangga University. ISBN 978-979-17677$1-2$.

Yusiati, L.M., Z. Bachruddin, C. Hanim, H. Musyaiddah. 2008. Addition of sardine oil as reducing methanogenesis agent on in vitro rumen fermentation of king grass. Proceedings. The $13^{\text {th }}$ of Animal Science Congress of The Asian-Australasian Association of Animal Production Societies. Hanoi, Vietnam. 